\title{
ORAL CONTRACEPTIVES AND THE RISK OF MYOCARDIAL INFARCTION
}

\author{
Bea C. Tanis, M.D., Maurice A.A.J. van den Bosch, M.D., Jeanet M. Kemmeren, Ph.D., Volkert Manger Cats, M.D., \\ Frans M. Helmerhorst, M.D., Ale Algra, M.D., Yolanda van der GraAf, M.D., and Frits R. RosendaAl, M.D.
}

\begin{abstract}
Background An association between the use of oral contraceptives and the risk of myocardial infarction has been found in some, but not all, studies. We investigated this association, according to the type of progestagen included in third-generation (i.e., desogestrel or gestodene) and second-generation (i.e., levonorgestrel) oral contraceptives, the dose of estrogen, and the presence or absence of prothrombotic mutations.
\end{abstract}

Methods In a nationwide, population-based, casecontrol study, we identified and enrolled 248 women 18 through 49 years of age who had had a first myocardial infarction between 1990 and 1995 and 925 control women who had not had a myocardial infarction and who were matched for age, calendar year of the index event, and area of residence. Subjects supplied information on oral-contraceptive use and major cardiovascular risk factors. An analysis for factor $V$ Leiden and the G20210A mutation in the prothrombin gene was conducted in 217 patients and 763 controls.

Results The odds ratio for myocardial infarction among women who used any type of combined oral contraceptive, as compared with nonusers, was 2.0 (95 percent confidence interval, 1.5 to 2.8). The adjusted odds ratio was 2.5 (95 percent confidence interval, 1.5 to 4.1) among women who used second-generation oral contraceptives and 1.3 (95 percent confidence interval, 0.7 to 2.5 ) among those who used third-generation oral contraceptives. Among women who used oral contraceptives, the odds ratio was 2.1 (95 percent confidence interval, 1.5 to 3.0) for those without a prothrombotic mutation and 1.9 (95 percent confidence interval, 0.6 to 5.5) for those with a mutation.

Conclusions The risk of myocardial infarction was increased among women who used second-generation oral contraceptives. The results with respect to the use of third-generation oral contraceptives were inconclusive but suggested that the risk was lower than the risk associated with second-generation oral contraceptives. The risk of myocardial infarction was similar among women who used oral contraceptives whether or not they had a prothrombotic mutation. (N Engl J Med 2001;345:1787-93.)

Copyright (1) 2001 Massachusetts Medical Society
$\mathrm{T}$

HE first report of coronary thrombosis associated with the use of oral contraceptives appeared in 1963. ${ }^{1}$ Later studies established the use of oral contraceptives as a risk factor for venous as well as arterial thrombosis. ${ }^{2} 7$ Various modifications were made in an attempt to lower these risks, including a reduction in the estrogen dose and changes in the progestagen compound. Oral contraceptives containing an estrogen and the progestagen desogestrel or gestodene, available since the $1980 \mathrm{~s}$, are associated with at least a doubling of the risk of venous thrombosis as compared with other combined oral contraceptives. ${ }^{8} 12$ It has been suggested that these third-generation contraceptives protect against myocardial infarction by having a favorable effect on the lipid profile, ${ }^{13} 15$ because studies showed that women who used these types had a slight increase in the level of high-density lipoprotein cholesterol. ${ }^{15,16}$ Only a few studies of the association between oral contraceptives and myocardial infarction have included a direct comparison of third- and second-generation progestagens, and the results have been contradictory. ${ }^{1721}$ We investigated whether the use of low-dose combined oral contraceptives affects the risk of myocardial infarction. We assessed the effect of the type of progestagen included in the oral contraceptive (levonorgestrel as compared with gestodene or desogestrel), the dose of estrogen, and the presence of the G1691A mutation in the factor $\mathrm{V}$ gene (factor $\mathrm{V}$ Leiden) and the G20210A mutation in the prothrombin gene, which have been assocrated with myocardial infarction in young women ${ }^{22,23}$ as well as with a particularly high

Fiom the Thrombosis and Hemostasis Resealch Center, Department of Hcmatology (B C T, FR R), and the Departments of Cardiology (VMC), Obstetrics, Gynccology, and Reproductive Medicanc (FM H), and Clincal Epidemology (FR R), Lerden University Medical Center, Leiden, and the Juluus Center for General Practice and Patient Oriented Research (M A A J B , J M K , A A , Y G) and the Department of Neurology (A A), Unversity Medical Center, Utiecht - both in the Nethcrlands Address reprint iequests to Dr Rosendaal at the Department of Clinical Epidem ology, Lciden Unuveisity Medical Center, Bldg 1, C9 P, PO Box 9600, 2300 RC Leiden, the Netherlands, or at $\mathrm{f}$ r losendaal@lume nl

Repnted from THF NEW ENGLAND JOURNAL OF MEDICNNE (ISSN 0028-4793) Vol 34517871793 (Dcccmbcr 20, 2001)

Copyright (C) 2001 Massachusetts Medical Society All rights reserved

Prunted in the USA Fax (781) 8938103 www nejm org 
The New England Journal of Medicine

risk of venous thrombosis in women who use oral contraceptives 24

\section{METHODS}

\section{Study Design}

The Risk of Aiterial Thrombosis in Relation to Otal Contracep trves (RATIO) study is a population based case-control study of the relation of ar teisal disease to the use of or al contraceptives among women 18 to 49 years of age in the Nethellands The study proto col was approved by the ethics committees of the participating hos pitals (see the Appendix) Oral informed consent was obtamed from all participants

\section{Identification of Women with Myocardial Infarction}

Eligible patients were women 18 to 49 years of age who were hospitalized for a first myocardial infarction between January 1990 and Octobe1 1995 Mvocasdial infarction was defined by the pres ence of symptoms, elevated cardrac enzyme levels, and electrocar diogi aphic changes ${ }^{25}$ The patients were identified through a search of computerized hospital data bases for International Classification of Diseases, 9th Remusion, Clinucal Modrfacation codes for acute my ocardial infarction Of the 321 women who were admitted to the 16 participating centers during this period, 29 (9 percent) were excluded 19 died during admission, 9 died between discharge and the start of the study, and 1 was unable to participate The med ical records of all patients were reviewed by one investigator of the 292 1emanung patients, 21 could not be located and 23 declined to participate (icsponse rate, 85 percent)

\section{Control Women}

The study was designed to investigate three types of a1terial disease myocardial infarction, ischemic stroke, and peripheral arterial disease, the results for each type are reported separately We identufied and recruited one laige control group through random digit draling ${ }^{26}$ In this method, puvate telephone numbers random ly generated by a computer are dialed until someone answers or at least seven attempts have been made at val lous tmes of the day and the week, including the weekend We 1eached someone at 98 per cent of the numbers after a total of 15,725 telephone calls Once it was asceitaned that a household included a woman who was eligible for the study, she was asked to participate We reciuited con tuol women from the six geographic aicas where the patients lived, and using questionnautes, we assigned each an index year corle sponding to the one of the six years (1990 to 1995) in which the patients had had an index event Therefore, a contiol woman tan domly received one of six questionnanes conceining one of the inder years All questions clicited information about either the in dex date (in the case of questions about the body mass indes, mon opausal status, level of education, and family history), the yeat bufore the inder date (in the case of questions about a history of hyper tension, drabetes, hypercholesterolemra, alcohol use, and smoking), or the month before the index date (in the case of quicstions about the use of oral contraccptrves) The index date was the date of the myocaidial unfaiction in the patients and midyear in the controls To mummize age differences between the patrents and the controls, contiol women in the older age groups were oversampled by in cleasing the age limit of eligibility cuiteria durng ieciutiment The control group therefore was a population sample stratıfied according to age (in five year categonies), area of residence, and calcndar year

Eligible contiols weie women 18 to 49 veass of age who had no history of coronary, ceiebral, or peirpheral ai ter ial discase A total of 1259 eligible women were reached by random digit dialing, 925 of whom agieed to pat ticipate and retuined the questionnaire (73 peicent)

\section{Data Collection}

The standardized questionnare that was maled to patients and controls included questions about demographucs, use of oral contra ceptrves, reproductive history, height and weight, and the presence or absence of a history of hypertension, diabetes, hypeicholesterol emia, and cigarette smoking and a family history of cardiovascular diseasc Color photographs of all oral-contraceptive pills marketed in the Nethcilands dun ming the study penod were nncluded to help women recall the fomulatıons they might have used $\mathrm{O}_{1}$ al con tuaceptives were divided into fou gioups according to the type of progestagens included first-generation formulations contamng lynestrenol or norethindrone, second-generation formulations con tanng levonorgestrel, third generation formulations contaning desogestiel or gestodene, and oral contraceptives contaning an es togen and other progestagens (cyproteronc or norgestmate) or a progestagen alone We also classified or al contr aceptives accoiding to the dose of estrogen Women wele categorzed according to therr use of oral contraceptives (never, former, or cuntent) The level of education was categonized as primary school or less, secondary school, or higher education or unversity Obesity was defined as a body mass inder (the weight in kilogi ams divided by the squate of the height in meters) of at least $273^{23}$ Women were classified as having hypertension, diabetes, or hypercholesterolemia when they reported that the condition had been diagnosed by a physician on that they had been taking medication for the condition before the index date Smoking status was categonzed as never, for mer, or cur 1ent Current smokers were those who reported smoknng in the year betore the index date Alcohol use was catcgonzed as none, $\mathrm{l}$ to 15 dinks per week, and more than 15 drunks per week A famıly history of cardrovascular disease was defined as the occuircnice of nnyocardial infarction, stioke, or peipheral arteıal disease befoie the age of 60 years in one or more finst degree relatives

Samples of venous blood or buccal swabs were obtancd tiom 217 patients ( 88 percent) and 763 contiols ( 82 percent) who consented to undergo DNA analysis for factor $V$ Leiden and the G20210A mutation in the prothrombin gene The polymerase chan reaction was used for the analysis 2728

\section{Statistical Analysis}

We used unconditional logistic-regression analyses to calculate odds ratios fol the relation between the use of oral contraceptives and myocardial infarction, and we deisved confidence intervals from the model We adjusted for the thiee stratıfication factors - age (un five year categories), area of residence, and calendar yea - and for putative confounding factors (smoking status, presence or ab sence of hypercholesterolemia, diabetes, hypertension, obcsity, and a famuly history of cardıovascular disease, level of education, and alcohol intake) To cxclude an effect of the dose of estrogen in the analyses that werc focused on the type of progestagen included in the oral contraceptive, we excluded women who used formu lations other than those contamung $30 \mu \mathrm{g}$ of ethmyl estradiol 28 women ( 13 patients and 15 contiols) used second generation oral contraceptives containing $50 \mu \mathrm{g}$ of ethinyl cstradiol, 67 women (13 patients and 54 contiols) used triphask second genetation oral contracepuves, 3 women (all controls) used tuphasic thud generation oral contraceptives, 18 women ( 2 paticnts and 16 con trols) used thind generation oral contraceptives contaning $20 \mu \mathrm{g}$ of ethinyl estradiol, and in 6 women ( 1 patient and 5 contiols) the dose of ethunvl estradiol was unknown In a fir ther effort to minumize the possibility of confoundung, in paiticulat by the presence of preexisting discasc, we rcpeated the analysis aftcr ex cludning women with major cardiovascular isk factors We also di rectly investigated whethu confounding was present, in particuln presciption bias, by analy ing usk factors and oral contraceptive use in the control women Analyses of the dose of cthinyl cstra diol werc restricted to women who used or al contraceptives con tannmg $50 \mu \mathrm{g}$ of ethmyl estradiol and $150 \mu \mathrm{g}$ of levonorgestiel or $30 \mu \mathrm{g}$ of ethinyl estradiol and $125 \mu \mathrm{g}$ of levonorgestrcl $\mathrm{F}_{1}$ nally, we assessed the effect of combinations of nisk tactors the use of oral contraceptives and conventional isk factors (current smokung, hypeicholesterolemia, diabetes, and hypertension), as well as factor $V$ Leiden and the G20210A mutation in the prothiom bu gene 


\section{RESULTS}

Table 1 shows the characteristics of the 248 women who had had a myocardial infarction and the 925 control women. Patients ranged in age from 24 to 49 years (mean, 43 ), and controls ranged in age from 18 to 49 years (mean, 38). Patients had a higher prevalence than controls of major risk factors for cardiovascular disease, such as hypertension (24 percent vs. 6 percent), hypercholesterolemia ( 11 percent vs. 3 percent), diabetes ( 6 percent vs. 1 percent), and current smoking ( 84 percent vs. 43 percent). Patients also had a lower level of education than controls (11 percent vs. 27 percent with post-secondary-school education).

The risk of myocardial infarction among users of any type of oral contraceptive was twice that of nonusers (95 percent confidence interval, 1.5 to 2.8 ), after adjustment for age, calendar year, and area of residence (Table 2). Additional adjustment for putative confounding factors increased the odds ratio in most age categories, and the overall risk remained doubled (Table 2). Women with no conventional risk factors (hypertension, hypercholesterolemia, diabetes, or smoking) who used oral contraceptives had a relative risk of myocardial infarction of 3.1 (95 percent confidence interval, 1.0 to 9.2). The duration of oralcontraceptive use did not differ significantly between patients and controls (median, 10 years).

Second-generation oral contraceptives containing levonorgestrel were used by 24 percent of the patients and 19 percent of the controls (Table 3). Third-generation oral contraceptives containing desogestrel or gestodene were used by 8 percent of the patients and 12 percent of the controls. The odds ratio for myocardial infarction was 2.8 (95 percent confidence interval, 1.3 to 6.3 ) for women who used first-generation contraceptives, as compared with those who had not used oral contraceptives; 2.4 (95 percent confidence interval, 1.6 to 3.6) for women who had used second-generation contraceptives; and 1.3 (95 percent confidence interval, 0.8 to 2.3 ) for women who had used third-generation contraceptives (Table 3 ). When we restricted this analysis to users of second-generation oral contraceptives (37 patients and 94 controls) and third-generation oral contraceptives ( 18 patients and 91 controls) that contained $30 \mu \mathrm{g}$ of ethinyl estradiol, the odds ratios did not change substantially: 2.7 for users of second-generation oral contraceptives (95 percent confidence interval, 1.6 to 4.3 ) and 1.6 for users of third-generation oral contraceptives (95 percent confidence interval, 0.9 to 2.9 ). A direct comparison of oral contraceptives containing $30 \mu \mathrm{g}$ of ethinyl estradiol and levonorgestrel, desogestrel, or gestodene revealed an odds ratio for myocardial infarction of 0.5 (95 percent confidence interval, 0.2 to 1.1) for third-generation as compared with second-generation oral contraceptives (after adjustment for stratification variables). The odds ratios were similar for third-generation brands containing desogestrel or

\begin{tabular}{|c|c|c|}
\hline \multicolumn{3}{|c|}{$\begin{array}{l}\text { Table 1. Characteristics of } 248 \text { Women } \\
\text { With a First MYOCARDIal INFARCTION } \\
\text { and } 925 \text { CONTROL WOMEN. }{ }^{*}\end{array}$} \\
\hline ChaRACteRISTIC & $\begin{array}{l}\text { Patients } \\
(\mathrm{N}=\mathbf{2 4 8})\end{array}$ & $\begin{array}{l}\text { ControLs } \\
(\mathrm{N}=925)\end{array}$ \\
\hline Age - yr & $427 \pm 65$ & $381 \pm 83$ \\
\hline White race - no (\%) & $234(94)$ & $864(93)$ \\
\hline $\begin{array}{l}\text { Level of education - no (\%) } \\
\text { Primary school or less } \\
\text { Secondary school } \\
\text { Higher education or university }\end{array}$ & $\begin{array}{r}130(53) \\
91(37) \\
26(11)\end{array}$ & $\begin{array}{l}278(30) \\
390(42) \\
252(27)\end{array}$ \\
\hline Hustory of hypertension - no (\%) & $59(24)$ & $56(6)$ \\
\hline $\begin{array}{l}\text { History of hypercholesterolemia } \\
\text { - no }(\%)\end{array}$ & $28(11)$ & $24(3)$ \\
\hline History of duabetes - no (\%) & $15(6)$ & $13(1)$ \\
\hline Body mass index & $257 \pm 51$ & $235 \pm 39$ \\
\hline $\begin{array}{l}\text { Smoking status - no (\%) } \\
\text { Never smoked } \\
\text { Former smoker } \\
\text { Current smoker }\end{array}$ & $\begin{array}{c}21(8) \\
19(8) \\
208(84)\end{array}$ & $\begin{array}{l}305(33) \\
222(24) \\
394(43)\end{array}$ \\
\hline $\begin{array}{l}\text { Family history of cardiovascular } \\
\text { disease - no }(\%)\end{array}$ & $156(65)$ & $311(36)$ \\
\hline Premenopausal — no (\%) & $205(83)$ & $767(83)$ \\
\hline
\end{tabular}

*Plus-minus values are means \pm SD Data on the level of education were missing for 1 patient and 5 controls, data on history of hypertension, history of diabetes, and smoking sta tus weie missing for 4 controls, data on hustory of hypercholesterolemia were missing for 5 controls, data on body-mass index (the weight in kilograms divided by the squarc of the herght in meters) were missing for 30 controls, and data on tamily history of cardiovascular disease were missing for 9 pa tients and 54 controls

gestodene. Further adjustment for confounding did not affect these estimates (Table 3 ).

In an analysis that was restricted to the 41 patients and 104 controls who had used contraceptives with a second-generation progestagen, as compared with those who had not used oral contraceptives, the risk of myocardial infarction was similar for oral contraceptives with different doses of estrogen. The odds ratio was 2.0 (95 percent confidence interval, 0.6 to 7.3) for brands containing $50 \mu \mathrm{g}$ of ethinyl estradiol with levonorgestrel and 2.6 (95 percent confidence interval, 1.6 to 4.2 ) for brands containing $30 \mu \mathrm{g}$ of ethinyl estradiol with levonorgestrel. A direct comparison of oral contraceptives containing levonorgestrel and ethinyl estradiol revealed an odds ratio of 1.7 (95 percent confidence interval, 0.4 to 7.9 ) for all brands that contained less than $50 \mu \mathrm{g}$ of ethinyl estradiol as compared with brands that contained $50 \mu \mathrm{g}$ of ethinyl estradiol or more.

We analyzed the effect of other cardiovascular risk factors in women who used oral contraceptives, as compared with the reference category of women who had not used oral contraceptives and who did not have the given risk factor (Table 4). The adjusted odds ratios for myocardial infarction among women who had not used oral contraceptives were 7.9 (95 percent con- 
The New England Journal of Medicine

Table 2. Odds Ratios for Myocardial Intarction among Women Who Used any Type of Oral Con rraceptive, According to Age *

\begin{tabular}{|c|c|c|c|c|c|c|}
\hline \multirow[t]{2}{*}{ AGE } & \multicolumn{2}{|c|}{$\begin{array}{l}\text { Patients } \\
(N=248)\end{array}$} & \multicolumn{2}{|c|}{$\begin{array}{l}\text { CONTROLS } \\
(\mathrm{N}=925)\end{array}$} & \multirow[t]{2}{*}{$\begin{array}{l}\text { OdDs Ratio } \\
\text { (95\% Cl)t }\end{array}$} & \multirow[t]{2}{*}{$\begin{array}{l}\text { Odds Ratio } \\
(95 \% \mathrm{Cl}) \neq\end{array}$} \\
\hline & $\begin{array}{l}\text { TOLAL } \\
\text { NO }\end{array}$ & $\begin{array}{l}\text { OC } \\
\text { USE }\end{array}$ & $\begin{array}{l}\text { TOTAL } \\
\text { NO }\end{array}$ & $\begin{array}{l}\mathrm{OC} \\
\text { USE }\end{array}$ & & \\
\hline \multicolumn{7}{|c|}{ no (percent) } \\
\hline $18-24 \mathrm{yr}$ & 2 & $1(50)$ & 69 & $57(83)$ & $04(001-100)$ & $08(01-109)$ \\
\hline $25-29 \mathrm{yr}$ & 8 & $6(75)$ & 118 & $88(75)$ & I $2\left(\begin{array}{ll}0 & 2-7\end{array}\right)$ & $38(15-92)$ \\
\hline $30-34$ yr & 27 & $18(67)$ & 140 & $71(51)$ & $26(09-71)$ & $62(11-357)$ \\
\hline $35-39$ yr & 31 & $12(39)$ & 167 & $52(31)$ & $16(07-37)$ & $57(13-246)$ \\
\hline $40-44 \mathrm{yr}$ & 60 & $29(48)$ & 170 & $39(23)$ & $27(14-53)$ & $34(13-87)$ \\
\hline $45-49$ yr & 117 & $33(28)$ & 252 & $41(16)$ & $20(12-35)$ & $17(08-33)$ \\
\hline Total & 245 & $99(40)$ & 916 & $348(38)$ & $20(15-28)$ & $20(14-30)$ \\
\hline
\end{tabular}

*For each age group, the women who had not used oral contraceptives served as the reference group Twelve women (three patients and nine controls) were excluded from the analysis it was not known whether seven controls had used oral contraceptives, and five women used hormone replace ment therapy (three patients and two controls) $\mathrm{OC}$ denotes oral contraceptive, and $\mathrm{CI}$ confidence interval

†Odds ratios were adjusted for the area of residence and calendar year

fOdds ratios were adjusted for the area of residence and calendar year, smoking status, presence or absence of hypertension, hypercholesterolemia, diabetes, obesity (a body mass index of at least 273 ), and a family history of cardiovascular discase, level of education, and alcohol intake

Table 3. Odds Ratios for Myocardial Infarction in ReLation to the Type of Progestagen Included in the Oral Contraceptive *

\begin{tabular}{|c|c|c|c|c|}
\hline \multirow[t]{2}{*}{$\begin{array}{l}\text { TYPE OF ORAL } \\
\text { CONTRACEPTIVE Used }\end{array}$} & $\begin{array}{l}\text { Patients } \\
(\mathrm{N}=\mathbf{2 4 8})\end{array}$ & $\begin{array}{l}\text { CONTROLS } \\
(\mathrm{N}=925)\end{array}$ & $\begin{array}{l}\text { Odds Ratio } \\
(95 \% \text { Cl }) t\end{array}$ & $\begin{array}{l}\text { ODds Ratio } \\
(95 \% \mathrm{Cl}) \neq\end{array}$ \\
\hline & \multicolumn{2}{|c|}{ no $(\%)$} & & \\
\hline Any type & $99(40)$ & $348(38)$ & $20(15-28)$ & $21(14-31)$ \\
\hline $\begin{array}{l}\text { First gencration } \\
\text { (lynestrenol or } \\
\text { norethindrone) }\end{array}$ & $11(4)$ & $31(3)$ & $28(13-63)$ & $27(10-73)$ \\
\hline $\begin{array}{l}\text { Second gencration } \\
\text { (levonorgestrel) }\end{array}$ & $59(24)$ & $173(19)$ & $24(16-36)$ & $25(15-41)$ \\
\hline $\begin{array}{l}\text { Third generation } \\
\text { (desogestrel or } \\
\text { gestodene) }\end{array}$ & $20(8)$ & $110(12)$ & $13(08-23)$ & $13(07-25)$ \\
\hline Other $\$$ & $9(4)$ & $28(3)$ & $23(09-56)$ & $21(07-64)$ \\
\hline
\end{tabular}

*For each comparison the group of women who had not used oral contraceptives (146 patients and 568 controls) served as the reference group Iwelve women (three patients and me controls) were left out of the analysis it was not known whether seven controls had used oral contraceptives, and five women used hormone replacement therapy (threc patients and two controls) The type of otal contraceptive used was unknown in stx controls $\mathrm{CI}$ denotes confidence interval

†Odds ratıos were adjusted for age, arca of residence, and calendar year

fOdds ratios wcre adjusted for age, area of residence, and calendar year, smokung status, presence or absence of hypertension, hypercholesterolemia, diabetes, obesity (a body mass index of at least 27 3), and a family history of cardiovascular discase, level of education, and alcohol intake

\$Thus category uncluded oral contraceptives contaming an estrogen and cither cyproteronc or nor gestımate or contauning a progestagen alone 
fidence interval, 4.9 to 12.9 ) for those who smoked, 5.l (95 percent confidence interval, 2.9 to 8.8 ) for those with hypertension, 3.3 (95 percent confidence interval, 1.6 to 6.8 ) for those with hypercholesterolemia, 4.2 (95 percent confidence interval, 1.6 to 109 ) for those with diabetes, and 3.4 (95 percent confidence interval, 2.2 to 5.3 ) for those who were obese. Among women who had used oral contraceptives, the risk of myocardial infarction was highest among those who smoked (odds ratio, 13.6), those who had diabetes (odds ratio, 17.4), and those who had hypercholesterolemia (odds ratio, 24.7).

Factor V Leiden or a G20210A mutation in the prothrombin gene was present in 18 of 214 patients ( 8 percent) and 58 of 760 controls ( 8 percent). Two control women carried both mutations. The odds ratio for myocardial infarction among women with a prothrombotic mutation was 1.1 (95 percent confidence interval, 0.6 to 1.9 ), as compared with women without a mutation. In the subgroup of smokers the presence of one of these mutations increased the risk of myocardial infarction by 1.6 (95 percent confidence interval, 0.8 to 3.3 ). Among women young- er than 35 years of age who had a prothrombotic mutatıon, the odds ratio was 1.6 ( 95 percent confidence interval, 0.4 to 5.8 ), and among those who were at least 35 years old it was 0.9 (95 percent confidence interval, 0.5 to 1.7 ). The use of oral contraceptives doubled the risk of myocardial infarction among women without a prothrombotic mutation (odds ratio, 2.1; 95 percent confidence interval, 1.5 to 3.0 ) and among women with a prothrombotic mutation (odds ratio, 1.9; 95 percent confidence interval, 0.6 to 5.5 ).

\section{DISCUSSION}

In this case-control study we found that the use of currently available combined oral contraceptives increased the overall risk of a first myocardial infarction. As compared with nonusers, women who used first- and second-generation oral contraceptives had a significantly increased risk, but the results were inconclusive for women who used third-generation oral contraceptives. The risk was increased in all age groups except for the small group of women who were 18 to 24 years old, and there were no significant differences in the odds ratios between the age categories

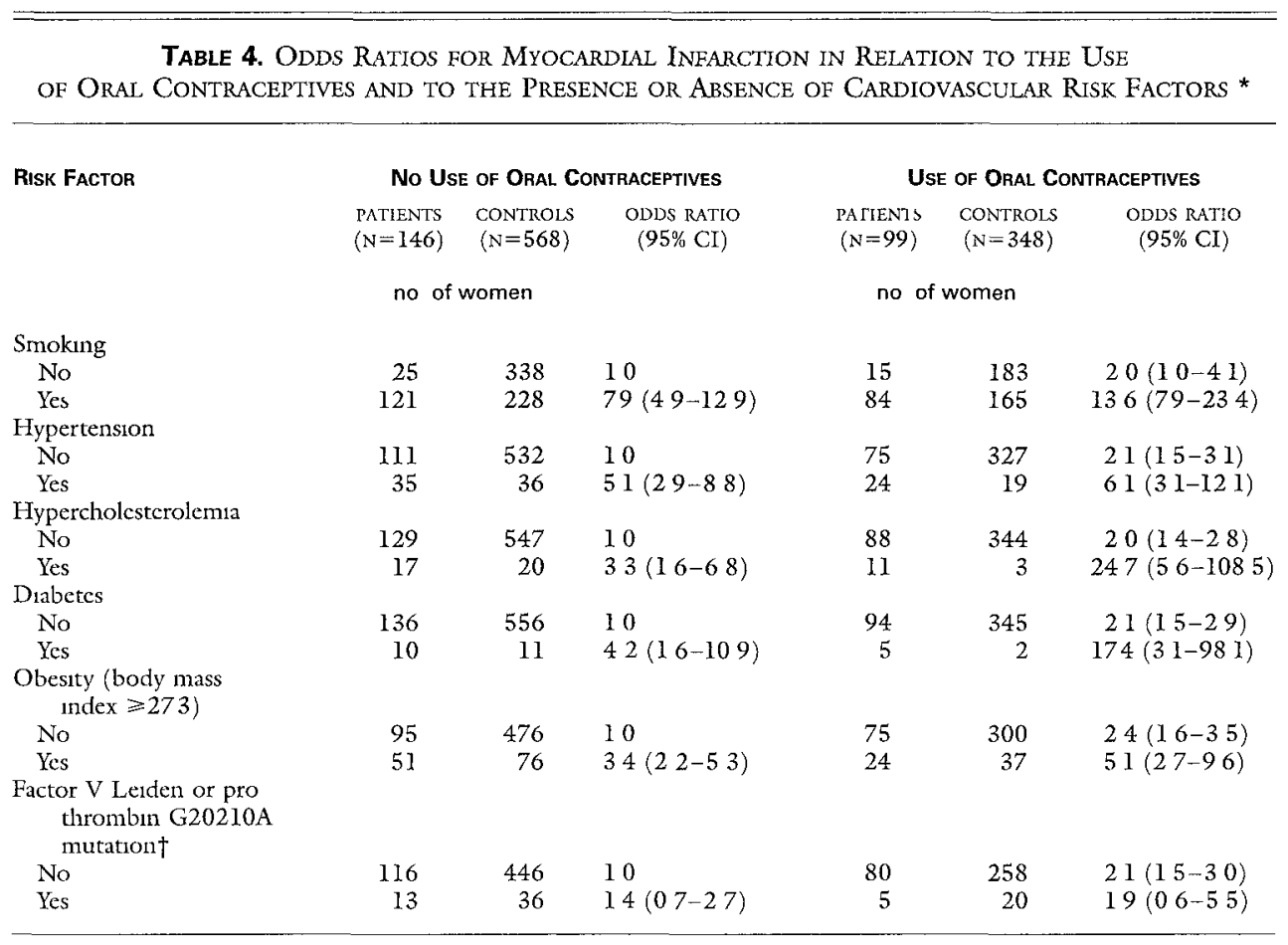

*Twelve women (thuee patıents and nune controls) were lett out of the analysis it was not known whether seven controls had used oral contraceptives, and five women used hormone replacement therapy (three patients and two controls) Data on smoking, hypertcnsion, hypercholesterolema, and dabetes were missing for 2 controls, and data on obcsity were miss ing tor 27 controls Odds ratios were relative to those of the icference groups (nonuscrs without the given risk factor) and were adjusted for age, area of Iesidence, and calcndar year $\mathrm{CI}$ denotes confidence interval

†A total of 217 patients and 763 contiols underwent DNA testing, DNA could not be analyzed in 3 patients and 3 controls 
or between the doses of estrogen. The risks were highest among users of oral contraceptives who smoked, who had diabetes mellitus, or who had hypercholesterolemia, but they were not affected by the presence of factor V Leiden or the G20210A mutation in the prothrombin gene.

The use of second-generation oral contraceptives increased the risk of myocardial infarction by a factor of 2.5. The use of third-generation oral contraceptives did not increase the risk significantly (odds ratio, 1.3). The direct comparison of second- and third-generation oral contraceptives suggested that the use of third-generation agents was associated with a lower risk of myocardial infarction, but the confidence interval was wide and therefore a definite conclusion could not be reached.

Five studies, including ours, have directly compared the effect of the use of second- and third-generation oral contraceptives on the risk of myocardial infarction, ${ }^{17}{ }^{21}$ with reported odds ratios that ranged from $0.3^{38}$ to $1.8 .^{21}$ Only the study by Dunn et al. ${ }^{21}$ and our study were designed to assess whether the use of thirdgeneration oral contraceptives has a different effect on the risk of myocardial infarction than does the use of second-generation agents and included a sufficient number of women who used third-generation oral contraceptives to allow conclusions to be drawn. Dunn et al. suggested that the risk is higher with third-generation than with second-generation oral contraceptives (odds ratio, 1.8; 95 percent confidence interval, 0.7 to 4.8 ), whereas we found the reverse (odds ratio, $0.5 ; 95$ percent confidence interval, 0.2 to 1.1 ). As can be seen from the confidence interval, the study by Dunn et al. also did not permit a definite conclusion to be reached.

Our study was designed as a nationwide, population-based, case-control study, with patients recruited from all eight academic centers in the Netherlands and eight surrounding hospitals. One of the strengths of our study is that the use of both second-and thirdgeneration oral contraceptives is widespread in the Netherlands, thus providing a large population of potential study subjects. In the evaluation of our results, we also need to address the possibility of bias. Because all patients with known myocardial infarction were hospitalized and the patients were selected entirely on the basis of the discharge diagnosis, selection bias is improbable. The rate of nonresponse was fairly low and was unlikely to have been associated with the use of oral contraceptives or the type of agent used. Information bias was unlikely, because the women were not told about the primary objective of the study and the questionnaire elicited information about many issues. The subjects' recall was optimized by the inclusion in the questionnaire of color photographs of all available oral contraceptives. ${ }^{29}$ However, the possibility of recall bias cannot be excluded. Patients who died after a myocardial infarction were not included in the study, but it is unlikely that the use of oral contraceptives would be a specific contributing factor to the case fatality rate.

Selective prescription following screening for risk factors may affect the risks associated with the use of oral contraceptives. We therefore investigated risk-factor status according to the use of oral contraceptives in the control women and found little difference in the prevalence of cardiovascular risk factors between those who used oral contraceptives and those who did not (Table 5). There were small differences in the incidence of hypercholesterolemia and diabetes and in body-mass index, which were in part explained by the younger age of oral-contraceptive users. To minimize the likelihood of confounding, we also conducted an analysis restricted to women with no cardiovascular risk factors and still found that women who used oral contraceptives had a risk of myocardial infarction that was three times the risk among nonusers.

Although the risk of myocardial infarction in users of oral contraceptives is small in absolute terms, it has an important effect on women's health, since 35 to

Table 5. Prevalence of Risk Factors for Cardiovascular EventS in CONTROL WOMEN, ACCORDING to THEIR USE of Oral Contraceptrves.*

\begin{tabular}{|c|c|c|}
\hline FACTOR & $\begin{array}{l}\text { Use of Oral } \\
\text { CONTRACEPTIVES } \\
(\mathbf{N}=\mathbf{3 4 8})\end{array}$ & $\begin{array}{l}\text { No UsE of OraL } \\
\text { CONTRACEPTIVES } \\
(N=568)\end{array}$ \\
\hline Age $-\mathrm{yr}$ & $332 \pm 83$ & $411 \pm 67$ \\
\hline $\begin{array}{l}\text { Level of education - no }(\%) \\
\text { Primary school or less } \\
\text { Secondary school } \\
\text { Higher education or unversity }\end{array}$ & $\begin{array}{r}90(26) \\
155(45) \\
100(29)\end{array}$ & $\begin{array}{l}183(32) \\
232(41) \\
152(27)\end{array}$ \\
\hline History of hypertension - no (\%) & $19(5)$ & $36(6)$ \\
\hline $\begin{array}{l}\text { History of hypercholesterolemia } \\
\text { - no. (\%) }\end{array}$ & $3(1)$ & $20(4)$ \\
\hline History of diabctes - no (\%) & $2(1)$ & $11(2)$ \\
\hline Body mass index & $229 \pm 40$ & $238 \pm 36$ \\
\hline $\begin{array}{l}\text { Smoking status - no (\%) } \\
\text { Never smoked } \\
\text { Former smoker } \\
\text { Current smoker }\end{array}$ & $\begin{array}{r}114(33) \\
69(20) \\
1.65(47)\end{array}$ & $\begin{array}{l}187(33) \\
150(27) \\
228(40)\end{array}$ \\
\hline $\begin{array}{l}\text { Alcohol mtake - no (\%) } \\
\text { None } \\
0-15 \text { drinks /wk } \\
>15 \text { dranks } / w k\end{array}$ & $\begin{array}{c}129(38) \\
206(60) \\
9(3)\end{array}$ & $\begin{array}{c}188(33) \\
343(61) \\
34(6)\end{array}$ \\
\hline $\begin{array}{l}\text { Family history of cardiovasculaı } \\
\text { disease - no }(\%)\end{array}$ & $104(32)$ & $203(38)$ \\
\hline
\end{tabular}

*Plus-minus values are means $\pm S D$ Nine women were excluded fiom the analysis it was not known whether scven women had used oral contraceptives, and two women used hor mone replacement therapy Data on the level of education were missing for 3 women who had used oral contraceptives and 1 woman who had not used them, data on smoking status were missing for 3 women who had not used oral contraceptives, data on alcohol intake werc missing for 4 women who had used oral contraceptives and 3 women who had not used them, and data on family history of cardiovascular disease were missing for 22 women who had used oral contraceptives and 29 who had not used them 
45 percent of women of reproductive age use oral contraceptives. ${ }^{30}$ Because all combined oral contraceptives are equally effective means of birth control, the issue of safety is paramount. Since the absolute risk of myocardial infarction is highly age-dependent, the risk associated with the use of oral contraceptives will have the greatest effect in older women. A large number of women who were 35 years of age or older still used oral contraceptives ( 26 percent). This finding, however, may be specific to the Netherlands (the rate is 24 percent in national statistics). ${ }^{30}$ Before prescribing oral contraceptives, clinicians should screen women for conventional risk factors for cardiovascular events, and they should remember that the most important advice they can give these women remains to quit smoking.

Supported by a grant (97-063) from the Netherlands Heart Foundation Di Helmerhoist has supcrvised tesearch studies sponsored by multiple pharmaceutical companes that manufactuc oral-contraceptive agents

We are indebted to Dr. Bruno Strucker for adpuce during the planning of the study, to Dr Jan Vandenbroucke and Dr. Tim Farley for critcoal veading of and advece on the analyses and writing, to Annemeeke van Dam for her work in contacting patzents and controls as well as for general data management, to Esther pan Lunteren and Marjon de Boer for their assistance in recruiting controls, to Tineke Krommenhoek-pan Es for the DNA analyser, to Dr Hans Vos for swpervision, and to all the women who participated in thes project

\section{APPENDIX}

The following investigators and centeis in the Netheilands particpated in the study Leiden University Medical Center, Leiden - E E van der Wall, Sunt Antonuns Hospltal, Nieuwegem - N M van Hemel, Academic Medical Cente1, Amstetdam - R J G Peters, Rinnstate Hospital, Arnhem - H A Bosker, Medual Center Haaglandun, Westende Hospital, The Hague - J Kolt, University Medual Cente1, N1jmegen-St Radboud FW A Verheugt, Lcyenburg Hospital, The Hague - B J M Delemane, University Medical Center, Rotterdam-Dilk LIgt - FA M Jonkman, Academic Hospital, Maastucht - F Vermeer, Rujnland Hospital, Leiderdorp - $C$ van Rees, Medical Center Frec University, Amsterdam - O Kamp, Unversity Medical Center, Uuecht - E O Robles de Meduna (deccased) Academic Hospital, Gronmgen $-M$ tan den Buig, Bionoro Hospital, The Hague - PR M van Dijkman, Sint Franciscus Hospital, Rotterdam - A schelling, and Diaconessenbuis Lerden - S A G J Witteveen

\section{REFERENCES}

1. Bove J, Favvett JW, Noall EWVP Coronay thombosis and Conond Lancet 1963,1111

2. Mann JI, Vessey MP, Thorogood M, Doll SR Myouatdial infarction in young women with special ieference to oral contraceptru pratuc Br Mud J 1975,22415

3. Jick H, Dinan B, Hem man R, Rothman KJ Myocardial infarction and other vascular diseases in voung women tole of cstrogens and other fac to1s JAMA 1978,240254852

4. Stadel BV Oial contraceptises and cardrosasculat discase N Fngl J Med $1981,305612-8$

5. Sartwdl PE, Stollcy PD Otal contraceptres and rascular discase Ep1 demol Rev 1982,495109

6. Thorogood $M$, Vessey MP An eprdemologk survev of catdrovascular discase un women taking oral contraccptives Am J Obstet Ginecol 1990, 16327481

7. Rosendaal FR. Thrombosis in the young cpidemology and 1 isk factors

a tocus on venous thombosis 7 hiomb Haemost 1997,78 16

8. Effect of ditterent progestagens in low oestrogen oral contraccptwes on venous thromboembolk disease World Health Organization Collaborative Study of Cardiovascular Discase and Stcroid Hoimone Contraception Lancet 1995,346 1582-8

9. Jick H, Jick SS, Gurewich V, Myeıs MW, Vasilakıs C Risk of idiopathic cardrovascular death and nontatal venous thomboembolism in women using oral contraccptives with diffening progestagen components Lancet 1995,346158993

10. Bloemenkamp KW, Rosendial FR, Helmerhorst HM, Bullc1 HR, Van denbroucke JP Enhancement by tactor V Leiden mutation of 1 isk of deep vein thrombosis associated with oral contaceptives contanung a thurd gen cration progestagen Lancet 1995,346 1593-6

11. Spitzci WO, Lewis MA, Hcincmann LA, Thorogood M, MacRac KD Thurd generation oral contraceptives and risk of venous thromboembolic disonders an international casc-contuol study BMJ 1996,312 83-8

12. Herings RM, Urquhart I, Leufkens $H G$ Venous thromboembolism among new users of different oral contraceptives Lancet 1999,354 1278 [Eiratum, Lancet 1999,3541478 ]

13. Godsland IF, Crook D, Simpson R, et al The effects of different for mulations of oral contraceptic agcuts on lipid and calbohvdrate metabolism N Engl J Med 1990,3231375 81

14 Spetoff L, DeCherney A Evaluation of a new generation of oral con traceptives Obstet Gynecol 1993,81 10344.7

15. Robnson GE Low dose combined oral contraceptuves Br J Obstet Gynaccol 1994,101 1036-41

16. Fotherby K, Caldwell AD New progestogens in oral contraception Contraception 1994,49 1-32

17. Jick $H$, Jick S, Myeis MW, Vasilakıs C Risk of acute myocardial in farction and low dose combined oral contraceptives Lancet 1996,347 6278

18. Lcwis MA, Spitzer WO, Heinemann LA, MacRac KD, Bruppacher R Thorogood $M$ Third generation oral contraceptives and risk of nyyocardial infaction an intcrnational case control study BMJ 1996,3128890 19. Lewis MA, Hememann LA, Spitzcr WO, MarRae KD, Bruppacher $R$ The use of oral contraceptives and the occurrence of acute myocardial infaction in young women results from the Transmational Study on Oral Contraceptives and the Health of Young Women Contraception 1997,56 $129-40$

20. Acute myocardial infarction and combined oral contraceptives results of an inteinational multicentre case control study WHO Collaborative Study of Cardiovascular Disease and Sterord Hormone Contraception Lancet 1997,34912029

21. Dunn N, Thorogood M, Faragher B, et al Otal contraceptives and myocardial infaction results of the MICA case control study BMJ 1999 $3181579-83$

22. Rosendaal FR, Siscovick DS, Schwatz SM, Psaty BM, Raghunathan I L, Vos HL A common prothrombin variant (20210 G to A) incieases the risk of myocardial infaiction in young women Blood 1997,90 174750

23. Rosendaal FR, Siscovick DS, Schwattz SM, er al factor V Lciden (resistance to actinated protem C) increases the rish of myocardial infarc tion in young women Blood 1997,892817 21

24. Vandenbrouche JP, Koster T, Buct E, Reitsma PH, Beituna RM, Rosendaal FR Increased rish of venous thiombosis in oral contraceptive useis who are canneis of tactor V Leiden mutation Lancer 1994,344 14537

25. Hucd LP, Bothan NO, Fnughe $P$, et al The Cardionasular Health Studv design and rationale Ann Epidemol 1991,1 263-76

26. Hatge P, Biuton LA, Roscnthal JF, Cahill JI, Hoover RN, Waksbug I Random digit dialing 111 selecting a population-based control group Am ) Epidemiol 1984,12082533

27. Butuna RM, Koclcman BP, Kostes $T$, ct al Mutation m blood coagu lation factor $\mathrm{V}$ associated with icsistance to activated protem $\mathrm{C}$ Naturc $1994,36964-7$

28. Poort SR, Rosendaal I R, Reitsma PH, Beituna RM A common genetw vanation in the $3^{\prime}$ untranslated 1 egion of the prothiombin gene is as

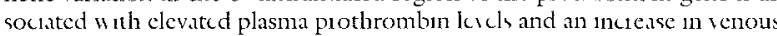
thiombosis Blood 1996,883698703

29. Hunter DI, Manson JE, Colditz GA et al Reproducibility of oral contraceptive histoncs and validity of homone composition icported in a cohort of US women Contraception 1997,56 3738

30. Central Bureau voon Statistick Statistisch jaaboek 1998 I he Hague, the Netherlands SDU/U1tgeren, 1998491

Copvight (0) 2001 Massachusetts Medıal Societv 


\section{The NeW England JOURNAL of MEDiCine}

OWNED AND PUBLished By the MASSAChUSETTS MEDICAL SOCIETY

The New England Journal of Medicine (ISSN 0028 4793) is published weekly in the Enghish language from Editorial Offices at 10 Shattuck Street, Boston, MA 021156094 USA - Fax (617) 7344457 Business and Subscription Oftices arc at 860 Winter Stıeet, Waltham, MA 02451 1412 USA - Fax (781) 893 0413, Tel (781) $8933800 \times 5515$, website www nejm org Those wishung to ordu subscriptions fiom outside The Americas may also contact European Magazine Distribution (EMD) - Fax (49) 303132032 (Bcrlın, Germany)

Matcrial printed in The NEJM is copyrighted by The Massachusetts Medical Society All ughts reselved No part of this repunt may be repioduced, displayed, or transmitted in any form or by any mcans without prior written permission from the Publisher Please contact the Permissions \& Licensing Department at 860 Winter Stiect, Waltham, MA 02451 USA, or tax permissions 1equests to (781) 434 7633 For bulk reprints plcase fax to (781) 8938103

The NEJM does not hold itself iesponsible for statements made by any contributor Statements or opinons expressed in The NEJM ieflect the views of the author(s) and not the official policy of the Massachusetts Mcdical Socicty unless so stated Repunts of at ticles published in The NEJM are distributed only as frec stinding educational matcrial They are not intended to cndorse ot promote any organization or its products or services 